\title{
The Impact of Reforming Saudi Arabia's Energy Policy by Developing the Solar Residential Industry: A System Dynamics Approach
}

\author{
AMRO A. BANJER \\ Graduate School of Technology Management, Ritsumeikan University, Osaka, Japan. \\ College of Engineering, University of Business and Technology (UBT), Jeddah, Saudi Arabia. \\ Email: banjar@gmail.com
}

ATSUSHI AOYAMA

Graduate School of Technology Management, Ritsumeikan University, Osaka, Japan.

\begin{abstract}
Saudi Arabia is highly dependent on oil for domestic energy consumption. This dependency costs the country its oil export supply. Remaining under this energy policy puts the country at risk of becoming an energy importer by 2038. Therefore, it is vital to find solutions to conserve energy, sustain new energy sources, and preserve most of the country's oil for strategic market control and exporting purposes. The author uses system dynamics (SD) modeling to simulate six scenarios from 2018 to 2030: the Saudi 2030 Vision's energy initiatives and the proposed policy, with a low, medium, and high oil price scenario for each simulation. The proposed policy will use a fixed capital of $\$ 2$ billion to invest in developing the solar manufacturing industry to mass produce solar power systems solely for residential consumers throughout the simulation period. All proposed policy scenarios showed positive results; they tremendously increased gross domestic product (GDP), managed to save oil by eliminating oil consumption, increased employment, and decreased carbon dioxide emissions. Additionally, results showed the sensitivity of oil price to the country's GDP; this is because of the high dependency on oil.
\end{abstract}

Keywords: System Dynamics, Oil, Solar Energy, Residential Electricity, Saudi Arabia, 2030.

\section{Introduction}

Oil subsidies are considered essential for various economies because they help to offset the high cost of living in these societies if renewables are absent. Otherwise, residents will spend a huge portion of their salaries on energy consumption, resulting in a weaker purchasing power that leads to weaker gross domestic product (GDP) over time.

Table 1 shows that the most affected countries are oil-dependent countries. When it comes to GDP, Saudi Arabia is most affected after Central Asian and Caucasus countries with a $14.34 \%$ decrease for every $60 \%$ drop in oil price.

Saudi Arabia is the most affected in consumption, with a $12.81 \%$ decrease for the same drop in oil price. In other words, the country will consume less oil if the price drops. However, residential consumption will not be affected because it increases at a constant rate annually. Nevertheless, the industrial and commercial sectors will be affected the most because the GDP was negatively affected. 
Table 1: The Impact of 60\% Drop in Oil Price on GDP.

\begin{tabular}{|c|c|c|c|c|c|}
\hline Country/Region & GDP & Consumption & Country/Region & GDP & Consumption \\
\hline World & 1.11 & 0.96 & $\begin{array}{l}\text { Rest of Europe and } \\
\text { Turkey }\end{array}$ & 0.48 & 0.57 \\
\hline Saudi Arabia & -14.34 & -12.81 & Mexico & -3.92 & -7.33 \\
\hline European Union & 1.92 & 1.52 & Argentina & 1.16 & 0.95 \\
\hline USA & 1.79 & 1.65 & North Africa & -2.79 & -2.14 \\
\hline Russia & -4.43 & -3.97 & New Zealand & 2.42 & 1.82 \\
\hline Canada & 1.67 & 1.3 & Iran & -5.21 & -3.68 \\
\hline Japan & 1.56 & 1.36 & South Africa & 2.45 & 2.02 \\
\hline Australia & 1.6 & 1.33 & Rest of Middle East & -8.58 & -6.32 \\
\hline China & 1.73 & 1.85 & Sub-Saharan Africa & -8.56 & -7.25 \\
\hline India & 3.21 & 2.59 & $\begin{array}{l}\text { Rest of Central and } \\
\text { S. America }\end{array}$ & 0.9 & 0.87 \\
\hline Indonesia & 3.24 & 2.88 & $\begin{array}{l}\text { Central Asia and } \\
\text { Caucasus }\end{array}$ & -15.2 & -5.88 \\
\hline Brazil & 2.65 & 2.05 & Southeast Asia & 2.95 & 2.58 \\
\hline $\begin{array}{l}\text { Republic of } \\
\text { Korea }\end{array}$ & 3.25 & 2.61 & $\begin{array}{l}\text { Rest of Asia and } \\
\text { Pacific }\end{array}$ & 3.32 & 3.02 \\
\hline
\end{tabular}

Source: JRC, GEM-E3 model

Oil-dependency is a bigger issue because Saudi Arabia is also an oil exporter. In that case, the subsidized main source of revenue is also the main source of consumption; this puts the country under economic pressure, especially if oil prices decrease. Saudi Arabia faced this pressure when the oil price started to drop in 2014, from its peak at $\$ 111.87$ per barrel to as low as $\$ 37.72$ a barrel in December 2015 and $\$ 30.80$ a barrel in January 2016. Resulting in a fiscal breakeven oil price higher than the averaged oil price for the years 2015, 2016, and possibly 2017, as shown in Table 2.

Table 2: Saudi Arabian Fiscal Breakeven Oil Price.

\begin{tabular}{|llll|}
\hline Year & $\mathbf{2 0 1 5}$ & $\mathbf{2 0 1 6}$ & $\mathbf{2 0 1 7} *$ \\
\hline Breakeven Oil Price & 94.8 & 66.7 & $70.2^{*}$ \\
\hline Oil Price & 52.4 & 44.0 & $57.0^{* *}$ \\
\hline
\end{tabular}

Source: International Monetary Fund (IMF)

* International Monetary Fund (IMF) projection

** Reuters projection

Failing to reach the breakeven oil price or higher resulted in a deficit of $\$ 98$ billion in 2015 and $\$ 79$ billion in 2016. In recent years, oil revenues averaged above $80 \%$ of the government's income, according to the Saudi Ministry of Finance, as shown in Table 3.

Table 3: Saudi Arabia's Annual Revenue Breakdown in Million Dollars.

\begin{tabular}{|lcccccc|}
\hline Year & $\mathbf{2 0 1 0}$ & $\mathbf{2 0 1 1}$ & $\mathbf{2 0 1 2}$ & $\mathbf{2 0 1 3}$ & $\mathbf{2 0 1 4}$ & $\mathbf{2 0 1 5}$ \\
\hline Oil Revenues & 106,667 & 124,800 & 165,600 & 193,867 & 196,000 & 155,013 \\
\hline Oil Revenue Percentage & $85.1 \%$ & $86.7 \%$ & $88.5 \%$ & $87.7 \%$ & $86.0 \%$ & $81.3 \%$ \\
\hline Other Revenues & 18,667 & 19,200 & 21,600 & 27,200 & 32,000 & 35,653 \\
\hline Other Revenue Percentage & $14.9 \%$ & $13.3 \%$ & $11.5 \%$ & $12.3 \%$ & $14.0 \%$ & $18.7 \%$ \\
\hline
\end{tabular}

Source: Ministry of Finance 
With this dependency, the price of oil affects the country's revenue directly, and over time oil consumption will exceed oil exportation. The previous energy policy was leading the country toward becoming an oilimporting country by 2038 (Lahn \& Stevens, 2011).

The Saudi Arabian energy policy made a couple of attempts to diversify energy production. In 2012, the government revealed a plan to install $41 \mathrm{GW}$ of solar energy by 2032. However, the government delayed the project; it decided to push the deadline to the year 2040. Later, in 2015 after the oil price crisis shook the world, the government decided to start over with its projects, but with the much smaller and faster accomplished goal of $9.5 \mathrm{GW}$ by 2023. Subsequently, the Vision 2030 initiatives embedded the $9.5 \mathrm{GW}$ projects.

The Saudi Vision 2030 is the roadmap for the economic development of the country; it is the first long-term plan the kingdom has ever undertaken. Usually, it has only 5-year long-term action plans. A team of consultants assigned by Crown Prince Mohammed bin Salman Al Saud, the king's son, created the Vision in 2016. According to the Saudi Arabian Oil Company Aramco, the Vision was a wakeup call after the 2015 budget deficit of $\$ 98$ billion.

Within the Vision is a program called the National Transformation Program 2020. Its role is to address difficulties and challenges through 2020; it consists of 543 initiatives with a total cost of $\$ 79$ billion over the year 2016 to the year 2020. In this research, the author reflects on initiatives that are related to energy and employment and their effect on GDP.

The country decided to decrease oil-related energy subsidies as part of the Saudi Vision 2030 initiatives, starting from 2018 (Bloomberg, 2017), as a way to increase its revenue while maintaining a societybenefitting cash-transferred form of subsidy for low-income households called the Citizen's Account initiative. However, even with the implementation of Citizen's Account, the root issue of inefficient energy generation and consumption remains. According to the journalist Eng. Albarjas, Saudi Arabia generates half of its electricity from oil, but other countries like the United States consume 1\% of oil for electricity generation, whereas Norway produces $90 \%$ of its electricity from waterfalls (Al Marsd, 2017).

Initially, the country's energy initiative is designed to develop $9.5 \mathrm{GW}$ of renewables by the year 2023, but this research will help decision-makers recognize and analyze the importance of investing further in the development of the solar industry, specifically small-scale residential systems. In addition to the increase in consumption of renewables, the proposed study will support an increase in industrial potential, a decrease in the Saudi unemployment rate, and a decrease in carbon dioxide emissions.

The Vision covers many aspects of the economy, although no plans have been announced for residential renewable or solar photovoltaic (PV) system projects. However, the above initiatives' goals harmonize with our study's goals, which are a decrease in dependency on oil, diversification of the economy's income, localization of the renewable energy industry, lowering of unemployment, and a decrease in carbon dioxide emissions. Our research aims at proving the importance of solar PV systems to residential consumers and the economy. Saudi Arabia is one of few countries that can manage to execute such a policy, sparing a few billion dollars on mega-projects without affecting its economy, even in the long run. The study will also support similar countries with similar economic power and high dependency on oil.

According to the Vision, the price of electricity will become higher than the oil reference price in 2018, meaning there will be a surplus of sales. Two billion dollars will be taken from residential electricity sales to fund the proposed mega solar residential project. Residential consumers consume the most energy in the kingdom, meaning a huge proportion of the sales will be coming from the residents. Thus, it will be practical to focus only on residential electricity sales from residential consumers, excluding the industrial, commercial, and governmental consumer sales from this study. 


\section{Literature Review}

\section{Energy Policy}

In their article, Chien and $\mathrm{Hu}$ (2015) analyzed the effects of renewable energy on the GDP of 116 economies using structural equation modeling methodology. The results of this approach showed that renewable energy had a great influence on GDP but an insignificant influence on the trade balance. The study further suggested that any energy policy related to increasing the formation of capital for renewable energies would be more beneficial to the economy than imposing taxes on imported fossil fuels.

Menegaki (2014) included 20 years of meta-analysis studies that concluded that an increase in GDP increases energy consumption with a ratio of 1 to 0.85 . However, Menegaki explained that the results are biased to some extent, although even with the bias, we can conclude that there is a relation between GDP and energy consumption.

A study by Al-mulali (2014) investigated the effects of nonrenewable and renewable energy on the economic sector. Both had a positive relation, but nonrenewable energy consumption had a more significant influence on economic growth than renewable energy consumption. One of the reasons for this implies that the investigated regions are still highly dependent on oil consumption. Therefore, Al-mulali concluded that it is important to invest in renewable energies to increase the consumption of renewables rather than oil energy. Another reason for renewable energy having a weaker influence on the economy is the cost of manufacturing renewables. At the time of the study, the cost of a solar PV panel cost per watt was around \$3; in 2017, according to Aramco, the cost of manufacturing $1 \mathrm{~W}$ is $\$ 0.43$. The price is decreasing and will continue to decrease considering the increase in demand and economy of scale.

For energy sustainability, studies suggested phasing out oil subsidies while phasing in renewable energy subsidies. The results of a Chinese study on the Chinese economy simulating scenarios of phasing out oil subsidies and phasing in solar energy subsidies showed that GDP would increase by $3.1 \%$ due to oil subsidy elimination, and energy intensity and carbon dioxide emission would decrease significantly (Ouyang \& Lin, 2014). Moreover, one scenario showed that GDP would also be affected negatively (by$4.46 \%$ ) by the macroeconomics, as would employment (by $-4.027 \%$ ).

Both decreases are too risky for the Chinese economy to eliminate oil subsidies instantly. Nevertheless, the other two scenarios showed that these negative effects on the economy could be lowered by $-0.886 \%$ ($0.432 \%$ of GDP) and $-0.795 \%$ ( $-0.393 \%$ of GDP) on employment if oil subsidies were decreased gradually by $20 \%$ or $10 \%$, respectively. However, in the scenarios of this study, an additional investment for the development of the solar energy industry was intended, and it exceeded the amount phased out from the oil subsidies. Results showed that additional government spending puts more strain on the economy in the short run.

Another study addressed the impact of reforming the energy policy of Malaysia on the Malaysian economy and the transportation sector (Solaymani \& Kari, 2014). Results indicated that the removal of subsidies will benefit Malaysia, increasing the GDP and decreasing oil energy consumption, which automatically decreases $\mathrm{CO} 2$ emissions. However, further results showed a significant decrease in household transportation usage; this also translates to lower exports and more imports by the country.

We understand from this study that introducing an energy alternative is essential if subsidies are to be removed, to avoid affecting households negatively and thus affecting the economy. Considering Saudi Arabia's case, households will not be affected severely due to the Citizen's Account initiative, but businesses and companies will take advantage of the increase in price by reflecting it upon households. 
A Saudi study by Kaboub, Forstater, and Kelsay (2015) measured the cost of unemployment on GDP using Okun's law, and employment in the solar industry is one of the solutions. Okun's law states that when unemployment decreases, GDP increases in a 1:2 ratio. However, this varies from country to country. The researchers found that for Saudi Arabia, a 1\% decrease in unemployment will increase GDP by $1.75 \%$ to $2 \%$. The results of the study showed that eliminating unemployment will result in an annual increase of $\$ 163.94$ billion to $\$ 259.53$ billion annually.

\section{SD and Policy Reforming}

Rozman, Kljajić, and Pažek (2017) conducted a study to recover the sugar beet industry in countries that have abandoned sugar beet production. Through modeling SD scenarios, results revealed that at the current intensity levels of yield and price, economically the production is feasible, meaning profit is expected from sugar beet production.

In a Chinese study by Xiao, Cheng, Shen, and Wang (2017), the researchers designed an SD simulation model for the natural gas industry of China. The goal was to analyze the influence of policy, technology, and investment in the natural gas industry. The simulation results showed that there are flaws in the pricing policy, and the way to improve it is by establishing a full market-based pricing system for the natural gas industry. Findings showed that technological improvements are necessary to increase reserve and production. Additionally, the scenario results showed the industry could do this efficiently by concentrating investments in research and development.

A study by Torres, Kunc, and Brien (2017) investigated the effect of implementing SD on five CEOs' internationalization strategies for their companies. All of the CEOs understood the mechanics of SD, but two out of five understood the results of their company's scenario simulations, leading them to improve their strategic initiatives and work performance a year later. From this study, we can conclude that for future implementation of projects, it is more beneficial to involve decision-makers in the process of designing SD modeling.

\section{Research Question}

The author asks the following question: What is the economic impact of investing in the development of the residential solar industry? Additionally, what is the environmental impact of investing in developing the residential solar industry?

With the implementation of the new energy policy suggested by the author, the mega-project is intended to transfer funds from the oil industry and feed it to the solar industry. Furthermore, breaking free of dependency on oil will diversify the country's income, which will lead the country to a greater strategic control of the oil market, an increase in GDP, and a decrease in unemployment and carbon dioxide.

\section{Approach}

\section{System Dynamics}

The approach of SD diagrams mainly includes causal loop diagrams (CLDs) and stock and flow diagrams (SFDs) to conceptualize and understand the complexity of nonlinear system behaviors better. CLDs consist of a system's main variables, their relations, and loops that formalize the system in a simplified form. An SFD, however, is more complex and more complete: It consists of variables, stock variables, and their flows. The stock variable is different from a normal variable; it accumulates or dissipates over the period of the simulation by the inflow or outflow links connected to it. 
Secondary data were used to complete the SD modeling for this research: two CLDs and one SFD. The CLDs are presented to illustrate the issue and the suggested solution for the consumption of oil for electricity. The models are Saudi Vision 2030, in this research referred to as the business as usual (BAU) model, and the solution (S) model. Both consist of six scenarios simulated in another model called the SFD.

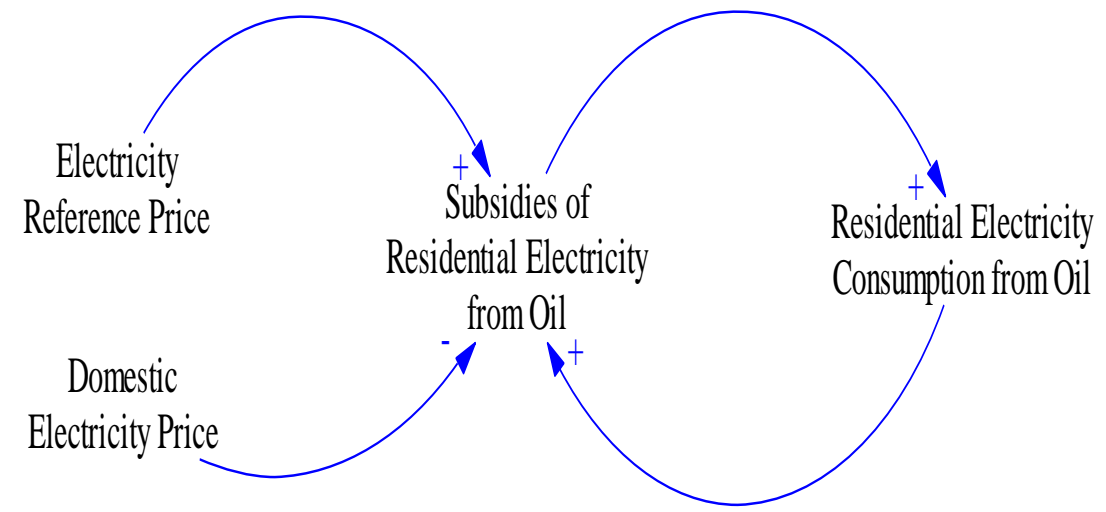

Figure 1: BAU Causal Loop Diagram Model.

In Figure 1, the model illustrates the current problem, showing the consumption of oil for residential electricity. The loop between residential electricity from oil and subsidies will continuously increase.

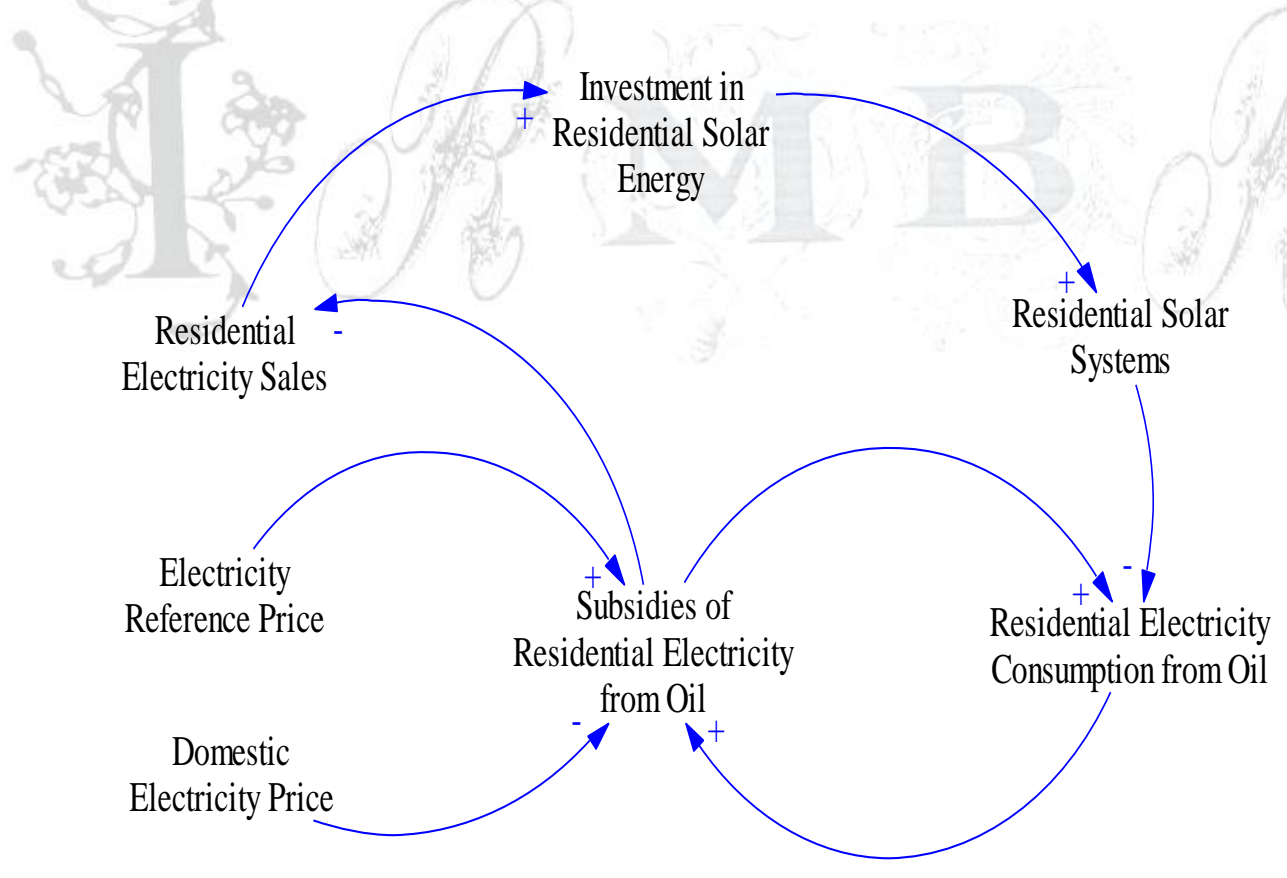

Figure 2: Solution Causal Loop Diagram Model.

Figure 2 demonstrates the solar investment variables. Introducing the residential solar system into this model prevents the conventional residential electricity consumption from increasing. 


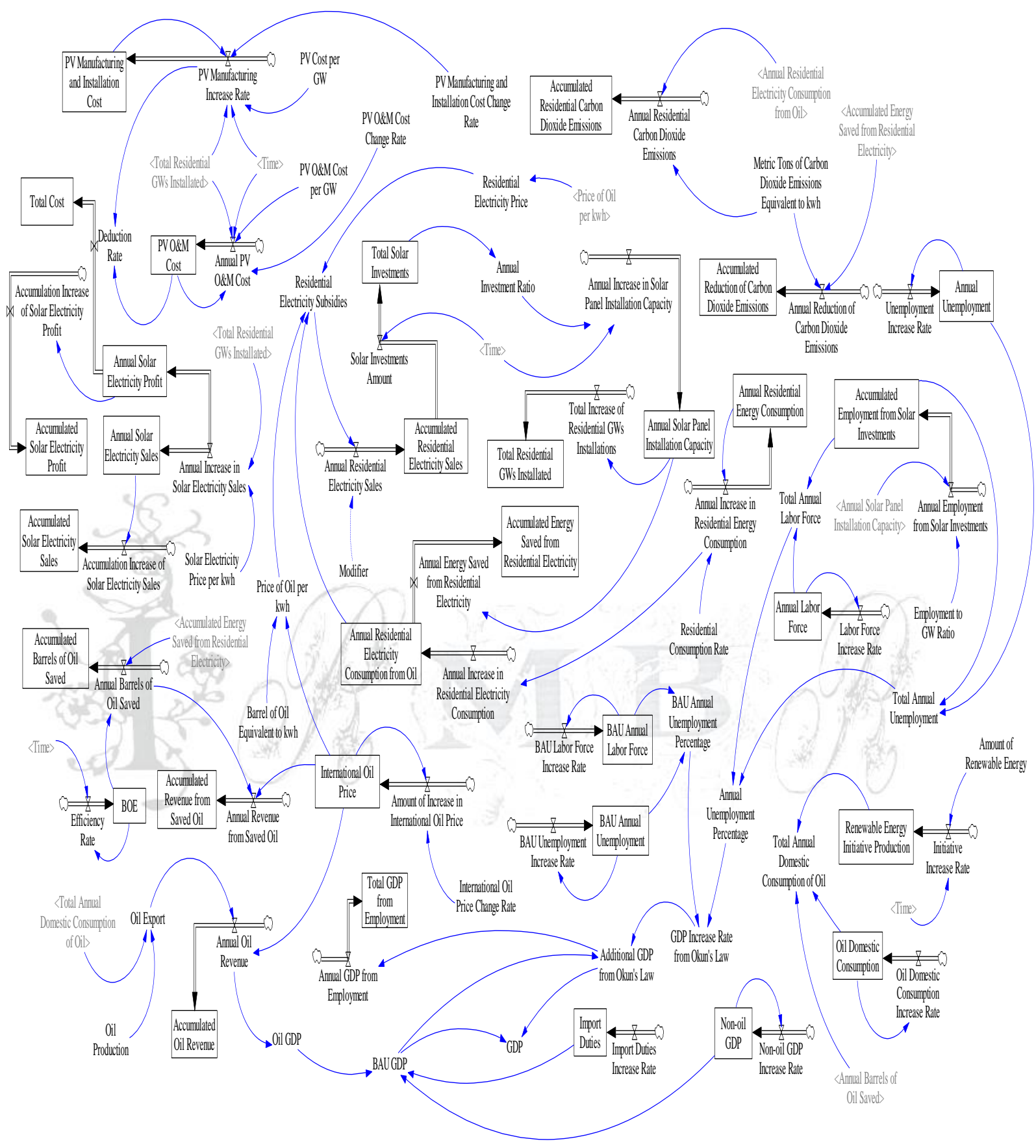

Figure 3: The Stock and Flow Diagram.

Figure 3 is the SFD that illustrates and simulates six scenarios: three BAU scenarios (low oil price BAU [LOP-BAU], medium oil price BAU [MOP-BAU], and high oil price BAU [HOP-BAU]) and three proposed scenarios (LOP-S, MOP-S, and HOP-S). Different variables are included, determining the results of GDP, residential consumption, solar panel investments, installation, barrels of oil saved, carbon dioxide emissions, and employment. 


\section{Scenario Modeling}

Lahn and Stevens (2011) predicted in one of their scenarios, their BAU scenario, that by 2038 Saudi Arabia would become an oil-importing country. Additionally, the study emphasized that this is a likely outcome if there are no new reserve discoveries, no decrease in population growth rate, and no change in policies and technologies. Their other scenarios focused on increasing energy efficiency to reduce oil consumption and increasing the consumption of renewables. This is a good solution, but further improvements are needed to transform the Saudi economy and maintain its leadership in producing and exporting different sources of energy, including renewables. Alyousef and Abu-ebid (2012) contributed a comparable study, but again it lacked the needed outputs to transform the Saudi economy.

In other research, Al-Ahmed (2012) used SD and explained in his thesis that Saudi Arabia is in grave danger if it continues with the same energy policy. He stated that by the year 2026, Saudi Arabia would consume half of its oil production; by the year 2047, it would consume all of its production, therefore becoming an oil-importing country. He proposed in his scenario a combined integrated solution through investing in energy efficiency, population awareness, and growth of solar power in the kingdom.

In this paper, we will focus on investing a fixed amount of funds for the residential solar industry. Enforcing the solar energy systems on households alone will increase consumer awareness, specifically among residential consumers. Additionally, the increase in price will make the consumer unlikely to increase demand, therefore acting as a support to energy efficiency without focusing on any technical renewable energy methods. Keep in mind that the distribution of systems will be targeted at lower-income households first, then gradually move up the ladder of households with higher incomes.

The three basic BAU scenarios (LOP-BAU, MOP-BAU, and HOP-BAU) and the three scenarios suggested by the researcher (LOP-S, MOP-S, and HOP-S) will simulate the different oil prices throughout the simulation, as shown in Figure 4. However, the figure shows three lines for LOP, MOP, and HOP because there are only three oil prices in the simulation.

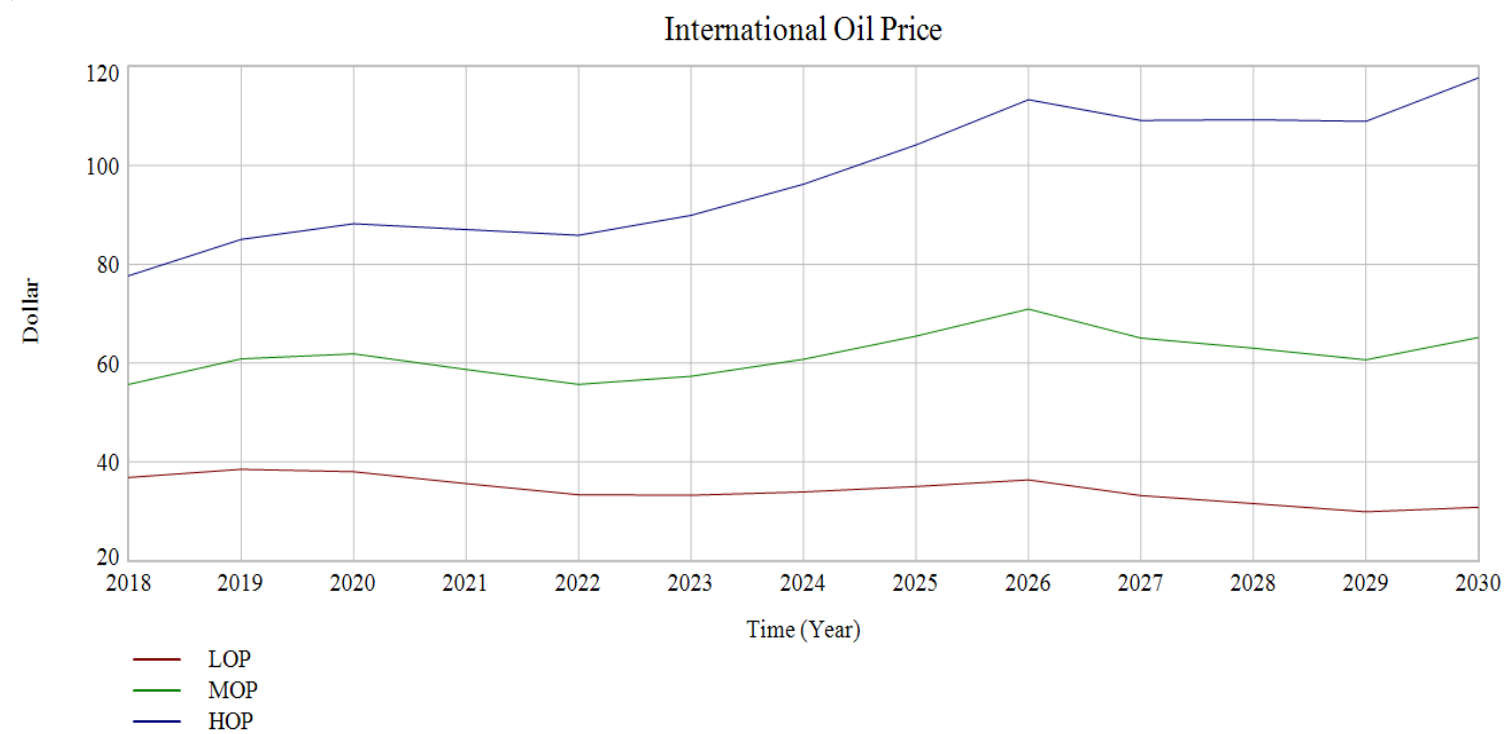

Figure 4.

LOP-S, MOP-S, and HOP-S are designed to start investing in the year 2018, but the installation will start in 2021 because of factory construction preparations, as shown in Figure 5. 


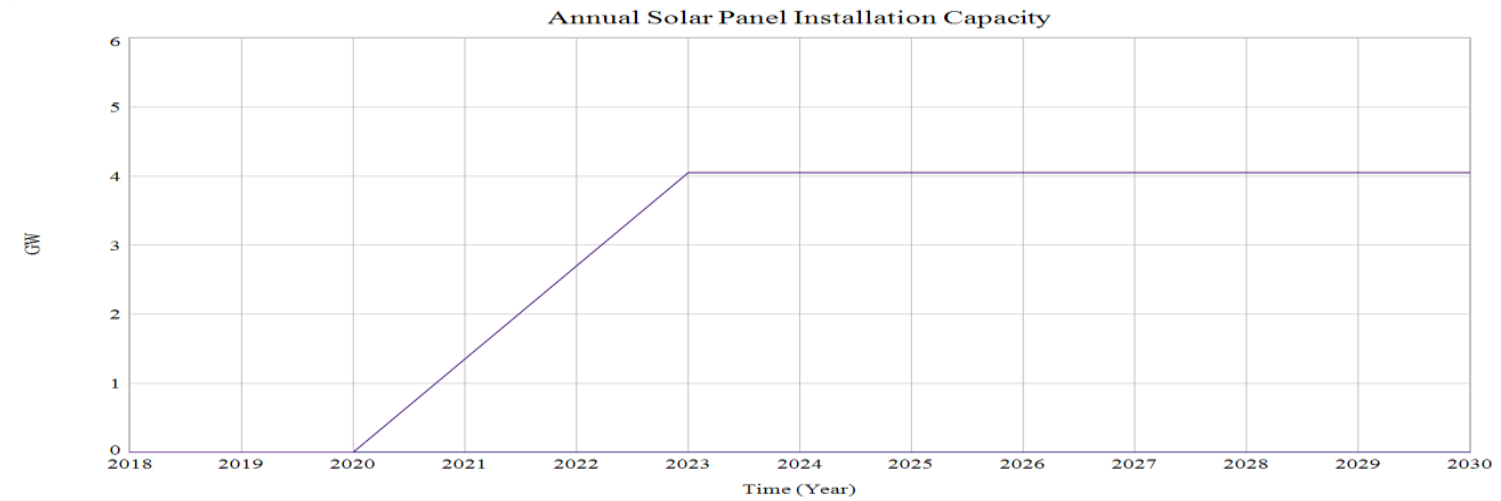

Figure 5.

An installation capacity of $1.35 \mathrm{GW}, 2.7 \mathrm{GW}$, and $4 \mathrm{GW}$ will be achieved in 2021, 2022, and 2023, respectively. The $4 \mathrm{GW}$ solar panel installation capacity will be constant from 2023 to 2030.

\section{Modeling Conditions}

-International Oil Price Condition

Oil price is hard to predict, which is why we designed three oil price patterns. The LOP uses a $\$ 40$ starting point with a randomized increase and decrease rate of $-10 \%$ to $5 \%$. MOP starts with $\$ 60$ with a change rate of $-10 \%$ to $10 \%$. HOP starts with $\$ 80$ with a change rate of $-5 \%$ to $10 \%$.

\section{-Domestic Electricity Price Condition}

According to Saudi Arabia's Vision 2030, the domestic electricity price will increase in 2018, by $\$ 0.05 / \mathrm{kWh}$ as a standard price and by $\$ 0.088 / \mathrm{kWh}$ when the price of oil becomes high. However, using high price without quantifying what constitutes a high price is subjective. That is why in our model we assumed that a high price would be above $\$ 0.046 / \mathrm{kWh}$, meaning the price of a barrel would need to be more than $\$ 75$ to change the price of domestic electricity to $\$ 0.088 / \mathrm{kWh}$.

Similarly, if the international oil price per kilowatt hour is higher than or equal to $\$ 0.046 / \mathrm{kWh}$, then the domestic electricity price would be $\$ 0.088 / \mathrm{kWh}$. A lower oil price makes the residential price remain at $\$ 0.05 / \mathrm{kWh}$, as shown in Figure 6 .

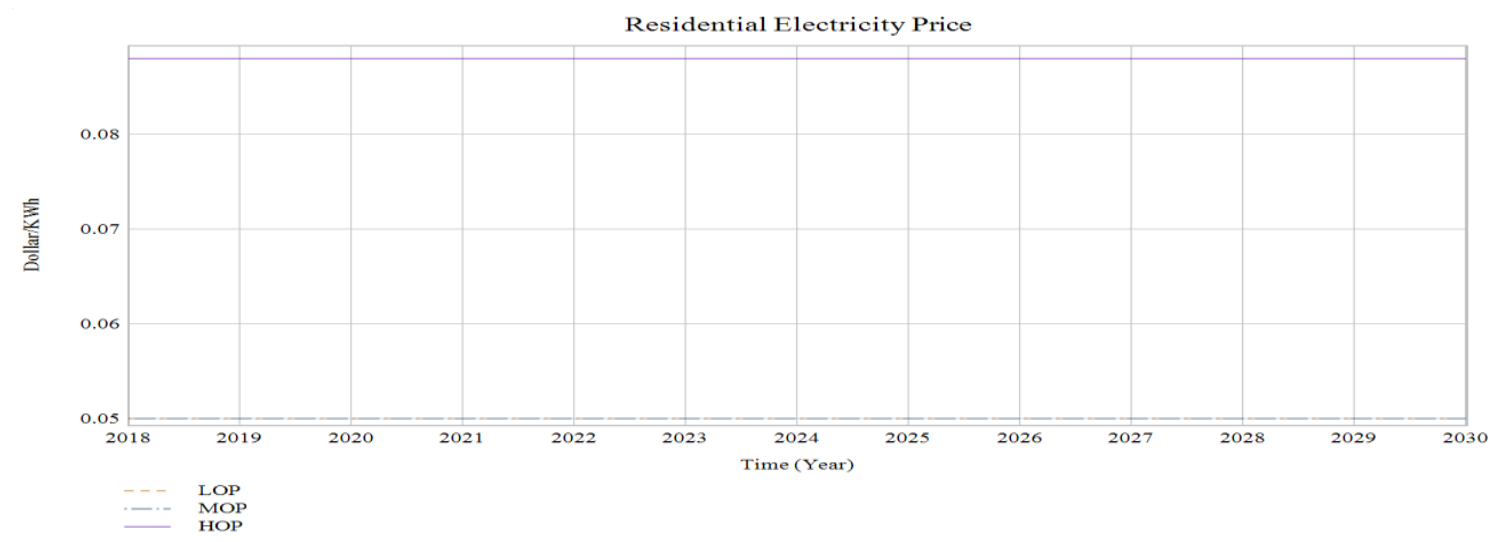

Figure 6. 
The LOP and MOP will remain at $\$ 0.05 / \mathrm{kWh}$ because in both scenarios oil price did not exceed $\$ 0.046 / \mathrm{kWh}$, unlike HOP, which will be at $\$ 0.088 / \mathrm{kWh}$.

-Subsidy and Sales Conditions

The Energy Information Association established a basic calculation to determine a consumed subsidy:

\section{Subsidy $=($ Reference Price - End-user price $) \times$ Units consumed}

The formula is normally the standard case when the reference price is higher than the end-user price, but with the Saudi Vision's new policy, the domestic price will become higher than the reference price by the beginning of 2018. The difference gives a negative result in the calculation; in other words, the government will get rid of residential electricity subsidies with the new policy and will have a surplus of sales from consumers, as shown in Figure 7.

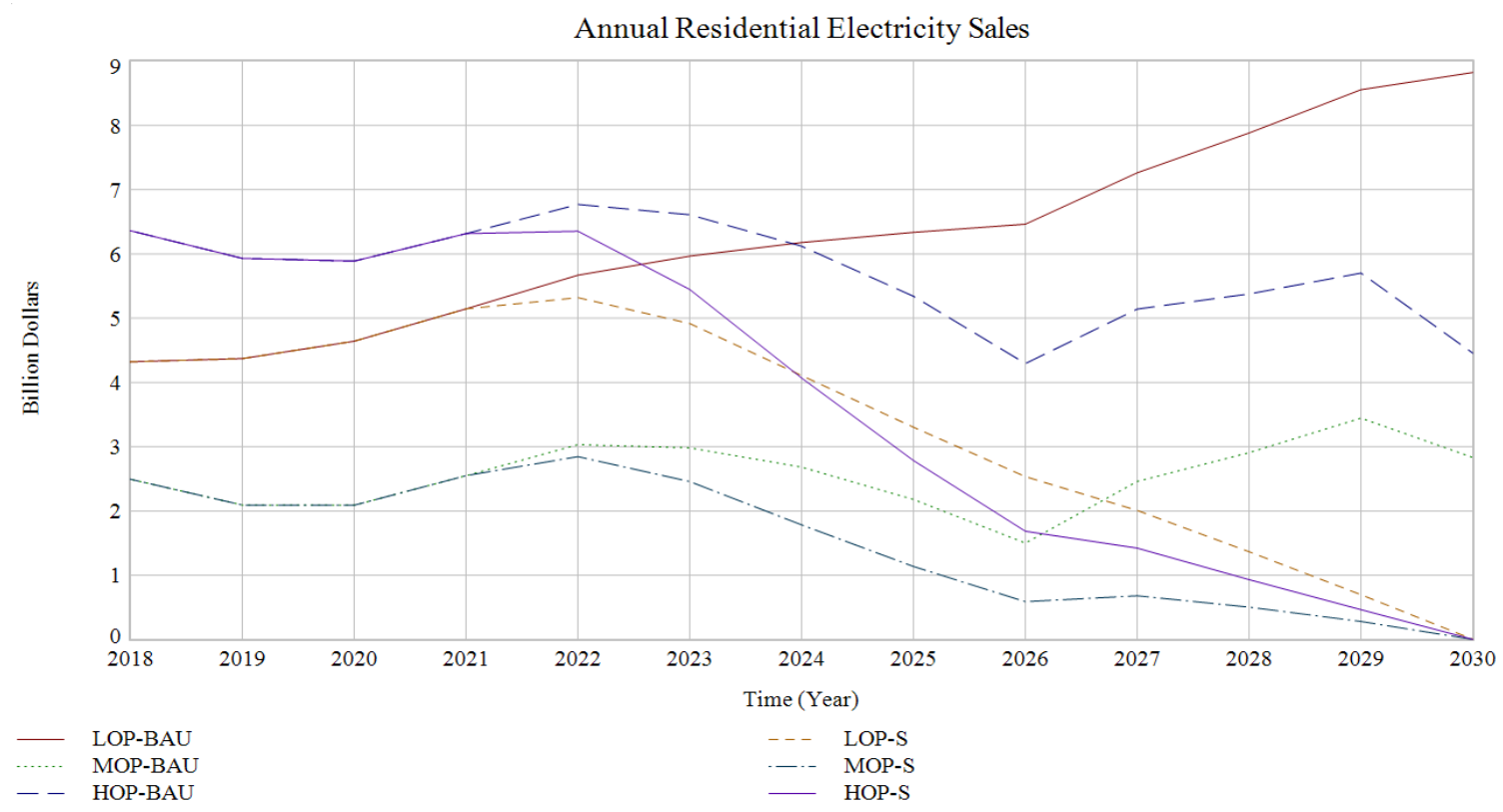

Figure 7.

From 2018 to 2020, both the suggested scenarios and the BAU scenarios have the same results. The difference starts in the year 2021, when the installation of residential solar systems begins. Additionally, all three suggested scenarios will not have any electricity sales from oil by the year 2030 .

\section{The Residential Solar Energy Industry Simulation Calculations}

-Residential Buildings

In a study done by Khan, Asif, and Stach (2017), the objective was to measure the potential of PV system installations for residential buildings in all regions of the Kingdom of Saudi Arabia in 2014. Additionally, they determined roof space availability after taking into account utilities and obstructive structures like heat ventilation and air conditioning, water tanks, and satellite dish antennas. Finally, they determined the power-generating potential of residential PV application. The results showed in 2014 that out of 951.6 million $\mathrm{m}^{2}$ of rooftop space, only 221.7 million $\mathrm{m}^{2}$ is usable for solar panel installation-23.3\% of total space. 
However, there is around $50 \%$ to $60 \%$ of unoccupied white land in major cities around the kingdom (Arab News, 2016). In March 2017, the government imposed a tax on individuals and businesses owning undeveloped land in cities (Al-Rifai, 2017). After the pressure of the imposed tax, we assume owners of undeveloped lands will develop their lands, and households will move to more spacious homes due to falling real-estate prices, thus meaning more spacious rooftop area. Furthermore, if we assume an increase of 330,000 houses annually, we will have 1,796 million houses by 2030 , for a total of 1,347 million $\mathrm{m}^{2}$ and a net space of 1,010 million $\mathrm{m}^{2}$.

\section{-Regional Radiation}

Radiation-wise, Saudi Arabia is considered one of the best geographical areas worldwide for solar panel installation (Figure 8). The eastern region has the lowest radiation, at $2,043 \mathrm{kWh} / \mathrm{m}^{2}$; the Najran region has the highest radiation, at $2,521 \mathrm{kWh} / \mathrm{m}^{2}$.

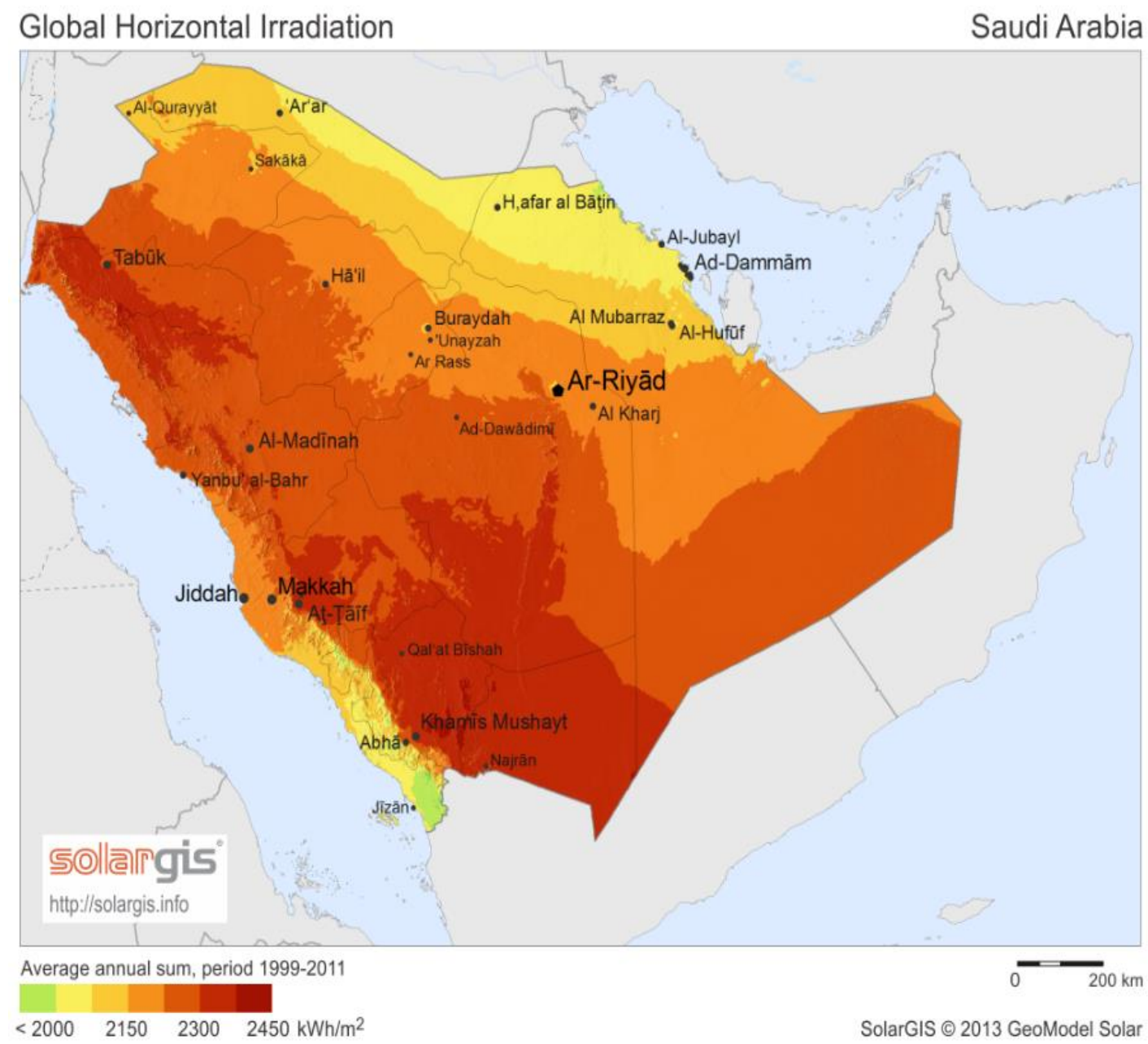

Figure 8 .

However, the eastern region has the third highest number of houses and amount of usable net space. In contrast, the Najran region is the fourth lowest region in terms of useable net space for installation. Therefore, taking a standard average of all the regions' radiation is not accurate. In Table 4, we calculate 
the radiation worth of each region by multiplying each region's net usable space by its radiation (in $\mathrm{kWh} / \mathrm{m}^{2}$ ), then dividing by 221 million $\mathrm{m}^{2}$, which is the summed area of all regions.

Table 4: Regional Radiation.

\begin{tabular}{|lcccc|}
\hline Region & $\begin{array}{c}\text { Net usable } \\
\text { roof area } \\
\left(\mathrm{m}^{2}\right)^{*}\end{array}$ & $\begin{array}{c}\text { Solar Radiation } \\
\left(\mathrm{kWh} / \mathrm{m}^{2}\right)\end{array}$ & $\begin{array}{c}\text { Radiation } \\
\text { Worth } \\
\left(\mathrm{kWh} / \mathrm{m}^{2}\right)\end{array}$ & $\begin{array}{c}\text { Radiation \% } \\
\text { Worth }\end{array}$ \\
\hline Al-Riyadh & $50,911,650$ & 2,193 & 503 & $22.5 \%$ \\
\hline Makkah Al- Mukarramah & $63,665,784$ & 2,194 & 630 & $28.2 \%$ \\
\hline Al-Madinah Al-Monawarah & $14,957,120$ & 2,326 & 157 & $7.0 \%$ \\
\hline Al-Qaseem & $10,032,494$ & 2,337 & 106 & $4.7 \%$ \\
\hline Eastern Region & $25,660,423$ & 2,043 & 236 & $10.6 \%$ \\
\hline Aseer & $17,710,182$ & 2,459 & 196 & $8.8 \%$ \\
\hline Tabouk & $6,624,043$ & 2,306 & 69 & $3.1 \%$ \\
\hline Hail & $5,267,866$ & 2,438 & 58 & $2.6 \%$ \\
\hline Northern Borders & $1,967,890$ & 2,061 & 18 & $0.8 \%$ \\
\hline Jazan & $13,620,289$ & 2,213 & 136 & $6.1 \%$ \\
\hline Najran & $4,764,553$ & 2,521 & 54 & $2.4 \%$ \\
\hline Al-Baha & $3,759,426$ & 2,472 & 42 & $1.9 \%$ \\
\hline Al-Jouf & $2,825,916$ & 2,165 & 28 & $1.2 \%$ \\
\hline Sum & $221,767,636$ & - & 2,233 & $100 \%$ \\
\hline
\end{tabular}

*Source: (Khan et al., 2017)

Thus, the average solar radiation of all regions is $2,233 \mathrm{kWh} / \mathrm{m}^{2}$.

-Residential Solar Manufacturing

H. Yamani (personal communication, August 19, 2017), a potential investor in the Saudi solar PV manufacturing industry, described the capital expenses required to build a high-end solar PV factory and operation in Saudi Arabia. Analyzing the given data and keeping in mind economy of scale, we conclude in our study that construction of a $4 \mathrm{GW}$ annual solar PV production requires a total of $\$ 2.041$ billion as of 2018 , or $\$ 0.302 / \mathrm{W}$. Manufacturing is divided into three phases: a $1.35 \mathrm{GW}$ installation capacity in 2021 , $2.7 \mathrm{GW}$ in 2022 , and the final phase to $4 \mathrm{GW}$ in the year 2023 , with a module efficiency of $25.5 \%$.

\section{-Levelized Cost of Energy}

Using all net space by 2030 will result in an energy capacity of $53.5 \mathrm{GW}$. However, $32 \mathrm{GW}$ by 2030 will cover $99 \%$ of residential energy needs if energy consumption increases from 158 billion $\mathrm{kWh}$ in the year 2018 to 284 billion $\mathrm{kWh}$ in the year 2030 .

By following the calculation application guide provided by the King Abdullah Petroleum Studies and Research Center (KAPSARC), we calculate the levelized cost of energy (LCOE) of our project (KAPSARC, 2016). In addition to the data analyzed in this research, we assume a panel lifetime of 25 years, a discount rate of $5 \%$, annual panel degradation of $0.4 \%$, and system derating factor of $81 \%$. These inputs will give us an LCOE of $\$ 0.025 / \mathrm{kWh}$. Therefore, we input in the simulation model a $\$ 0.03 / \mathrm{kWh}$ higher cost for solar electricity consumed by residential consumers.

\section{Model Testing}

Testing the model is an essential part of the SD approach, the test aims to check the variable similarities between model results and historical statistics. In our model, we chose the GDP variable as an indicator of a successful test, since it measures the economy size, and it is affected by the model's energy consumption, 
employment, and oil price variables. (Figure 9) shows two GDP lines over the period of 2010 to 2016, the GDP validation scenario and the GDP (Reference), the former represents the author's SD modeling GDP test result, and the later represents the actual GDP from historical data.

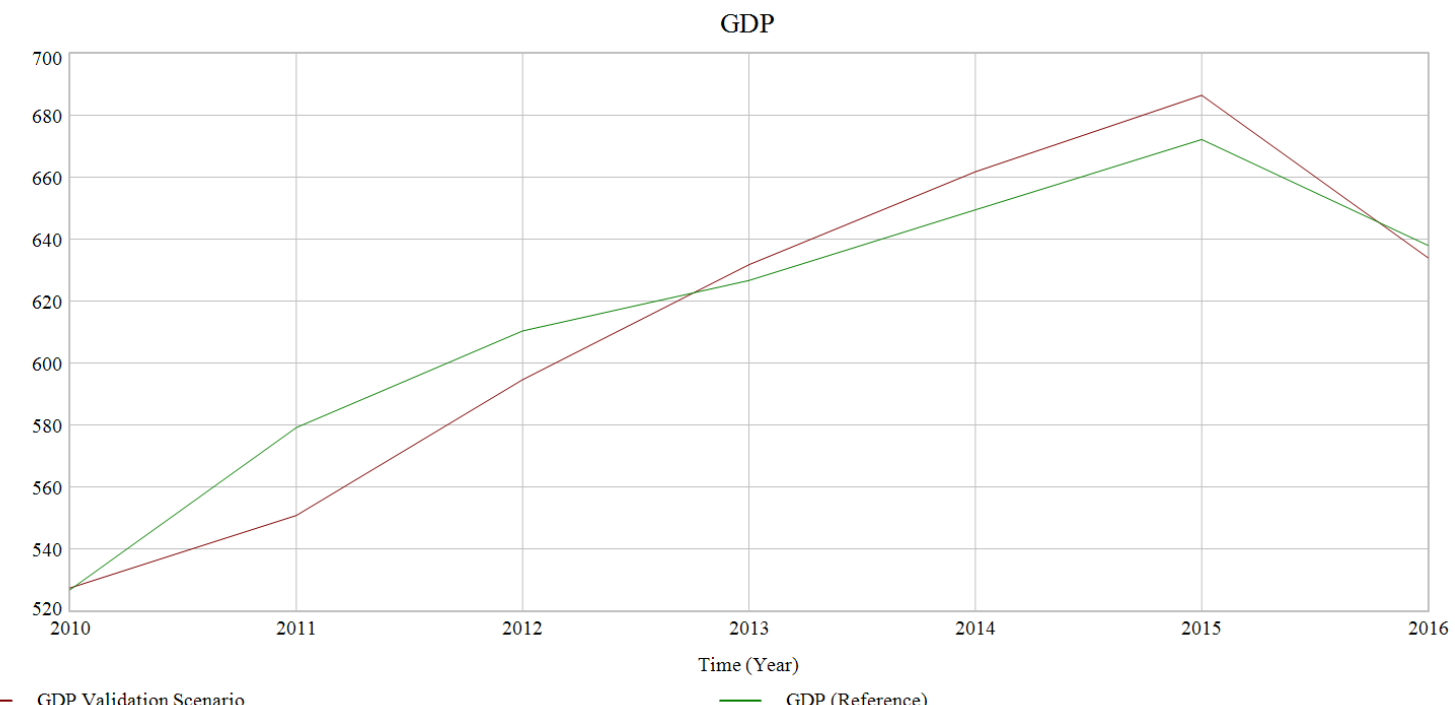

Figure 9.

\section{Results}

Oil

To Saudi Arabia, oil would be the resource with the highest importance for export worldwide; the less the country consumes, the more can be exported and thus used to control the oil market. Even after the country diversifies its economy with the new solar industry, combining oil and solar PV manufacturing will have a great impact on the economy.

To calculate the annual barrels of oil saved, we must multiply the accumulated energy saved from residential electricity by the barrel of oil equivalent (BOE), which equals 0.00235376 barrels for every 1 $\mathrm{kWh}$. The current BOE is four times less efficient by the international standard, which equals 0.000588441 per $1 \mathrm{kWh}$. This inefficiency is due to the weak performance of Saudi power plants, requiring additional oil to produce electricity (Al Marsd, 2017). In Figure 10, we can see a focused view of the model's variables related to oil savings.

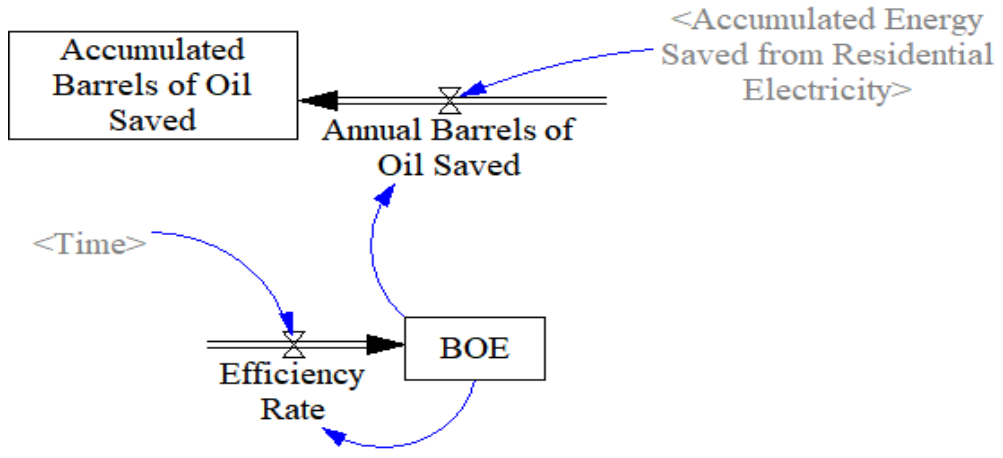

Figure 10: Barrel of Oil Saved Variables. 


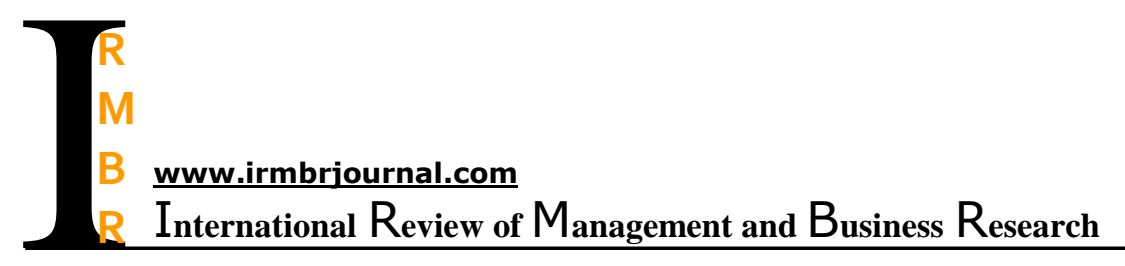

March 2018

By the year 2030, the country would be saving 893 million barrels of oil, as shown in Figure 11.

Vol. 7 Issue.1

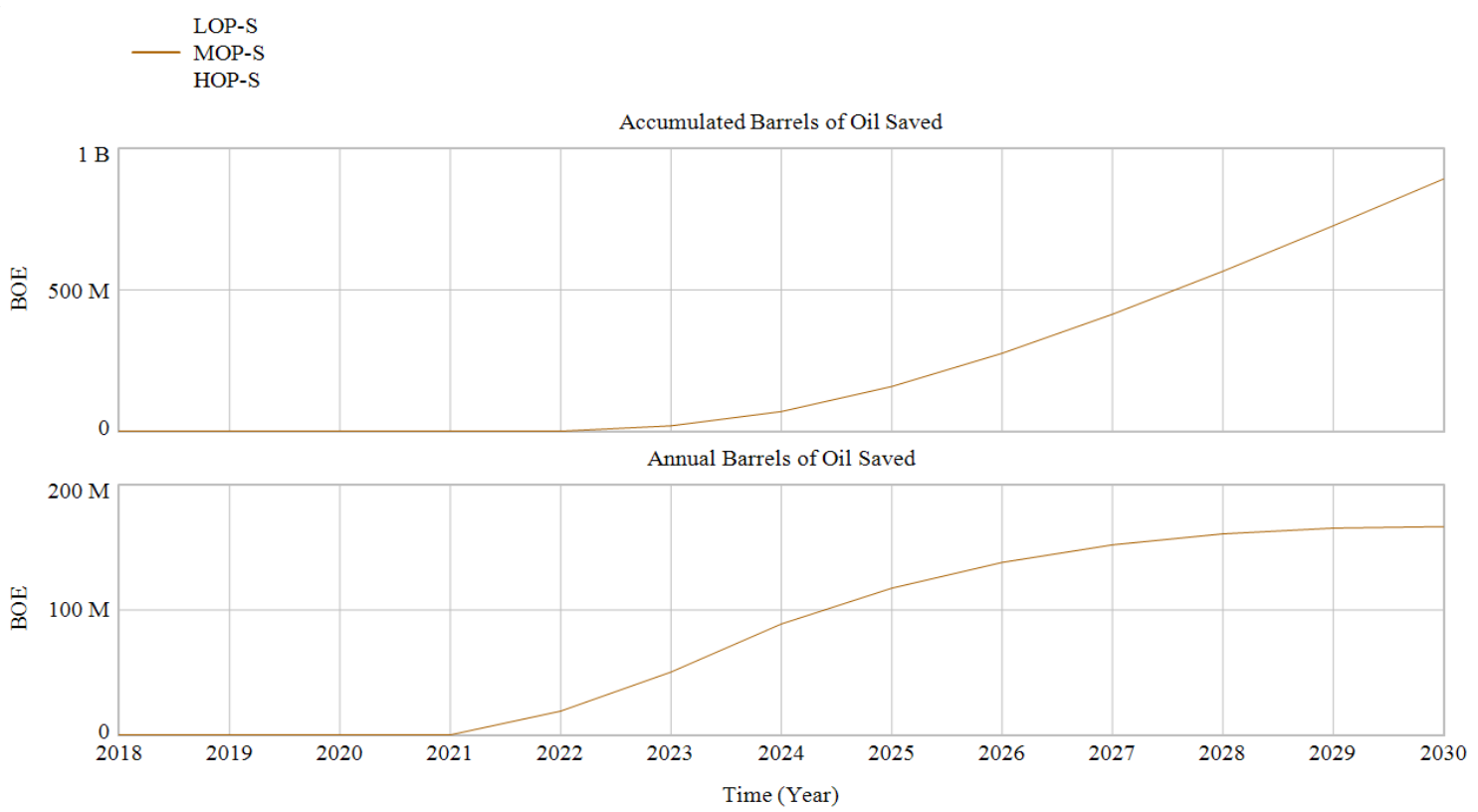

Figure 11: Total and Annual Barrels of Oil Saved.

This saving would mean an additional daily production of 2.4 million barrels for a year. As for oil revenues, depending on the oil price, we have the LOP-S with a total revenue of \$29.56 billion, MOP-S with $\$ 57$ billion, and HOP-S with $\$ 95$ billion, as shown in Figure 12.
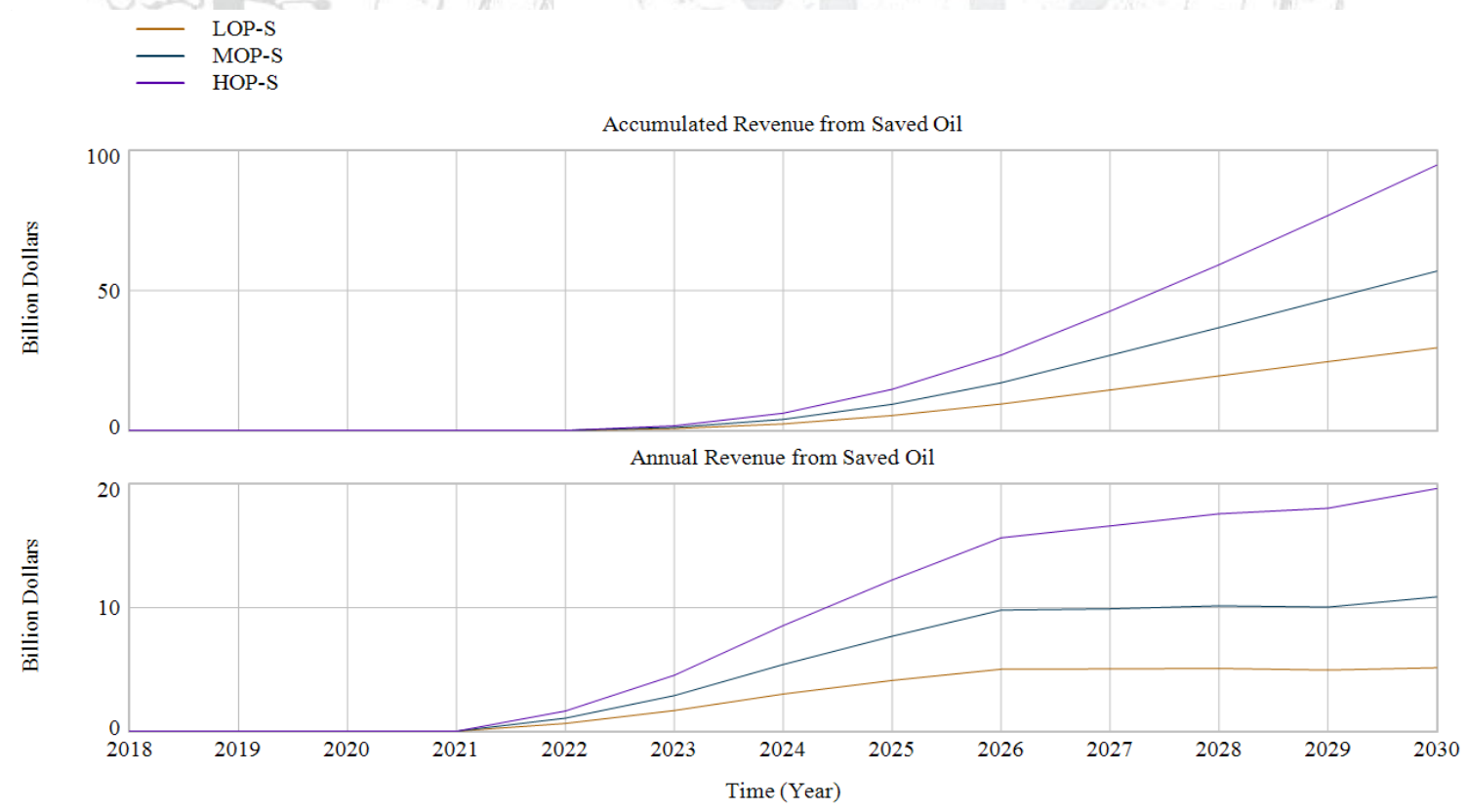

Figure 12: The Total and Annual Revenue from Saved Oil. 
The country's annual oil revenue, including the oil saved from the suggested scenarios, is shown in Figure 13.

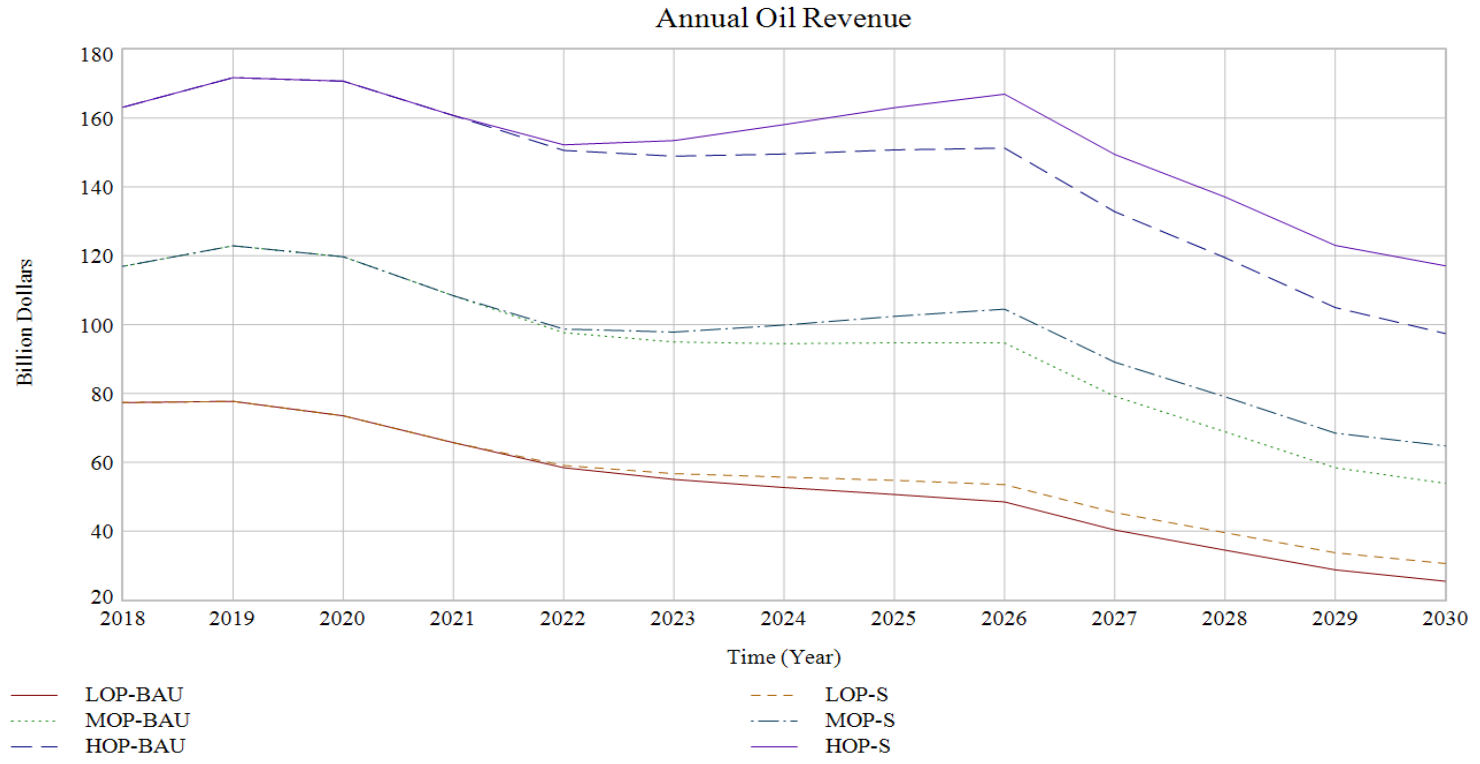

Figure 13.

By the end of the simulation, LOP-S has a total revenue of $\$ 780.2$ billion, exceeding LOP-BAU by an additional $\$ 30$ billion. The total revenue of MOP-S is $\$ 1,338.9$ billion, which is higher than MOP-BAU by $\$ 57$ billion. Lastly, HOP-S has a total revenue of $\$ 2,044.1$ billion, which exceeds the HOP-BAU revenue by $\$ 95$ billion.

\section{Solar Energy}

Currently, Saudi Arabia's residential electricity consumption is 150 billion kWh. In 2030, this amount is projected to almost double, reaching a consumption of 283 billion kWh, as shown in Figure 14.

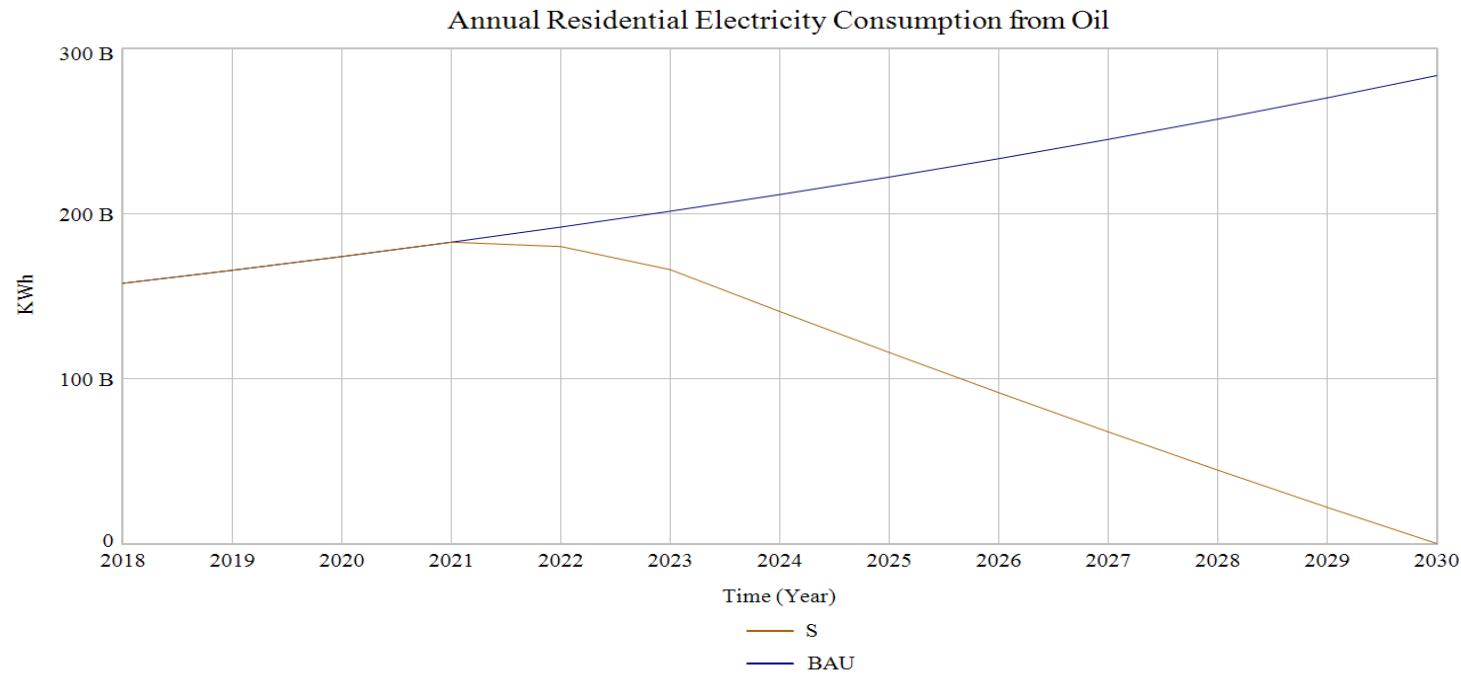

Figure 14. 
All suggested scenarios will nullify the residential electricity consumption of oil by 2030. In contrast, the residential solar energy capacity will increase by $32.4 \mathrm{GW}$, as shown in Table 5, saving and covering 283 billion $\mathrm{kWh}$ to almost all households, which account for 11.3 million residential customers.

Table 5: Total Residential GWs Installation.

\begin{tabular}{|ccc|}
\hline Year & GWs Installation & Annual Installation \\
\hline 2021 & 0.0 & 1.35 \\
\hline 2022 & 1.35 & 2.7 \\
\hline 2023 & 4.05 & 4.05 \\
\hline 2024 & 8.1 & 4.05 \\
\hline 2025 & 12.1 & 4.05 \\
\hline 2026 & 16.2 & 4.05 \\
\hline 2027 & 20.2 & 4.05 \\
\hline 2028 & 24.3 & 4.05 \\
\hline 2029 & 28.3 & 4.05 \\
\hline 2030 & 32.4 & 4.05 \\
\hline
\end{tabular}

\section{GDP and Employment}

It appears that by the year 2030, the development of the solar industry will make a huge impact on the economy in many ways.

The ratio in this study for employment is 34,000 employees for every $1 \mathrm{GW}$ of the installment, considering the need for rapid production and installation. Deriving the ratio from a study on the Japanese and European solar energy industries, Greenpeace (2013) stated that 20,000 manufacturing jobs and 13,000 installation jobs would be created from solar PV installation, in addition to 2,000 indirect jobs from other industries. However, in our study, the indirect jobs created from other industries are are half that of the Greenpeace study. Knowing that Saudi Arabia is still a developing country, jobs created indirectly are less likely to be available. Consequently, by 2030 , according to Figure 15, the employment created from the solar industry is 1.1 million jobs.

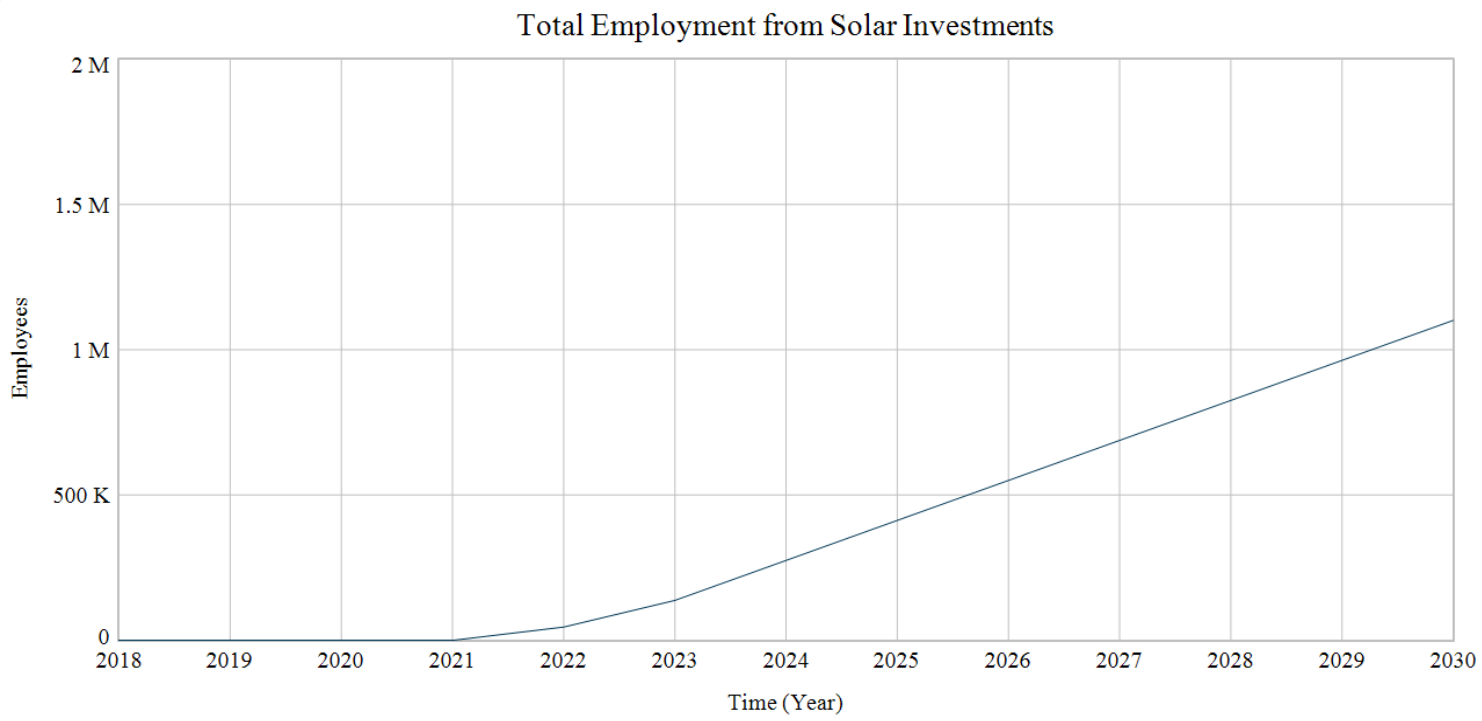

Figure 15. 
According to Okun's law, if unemployment decreases, GDP increases. Studies vary on the percentage of decrease and increase, depending on the country. A study on Saudi Arabia estimated that for every 1\% decrease in unemployment, the GDP would increase by $1.75 \%$ in one scenario and by $2 \%$ in another. In our research, the rate is randomized between $1.75 \%$ and $2 \%$ throughout the simulation. We show the results of the additional GDP from Okun's law in Figure 16.

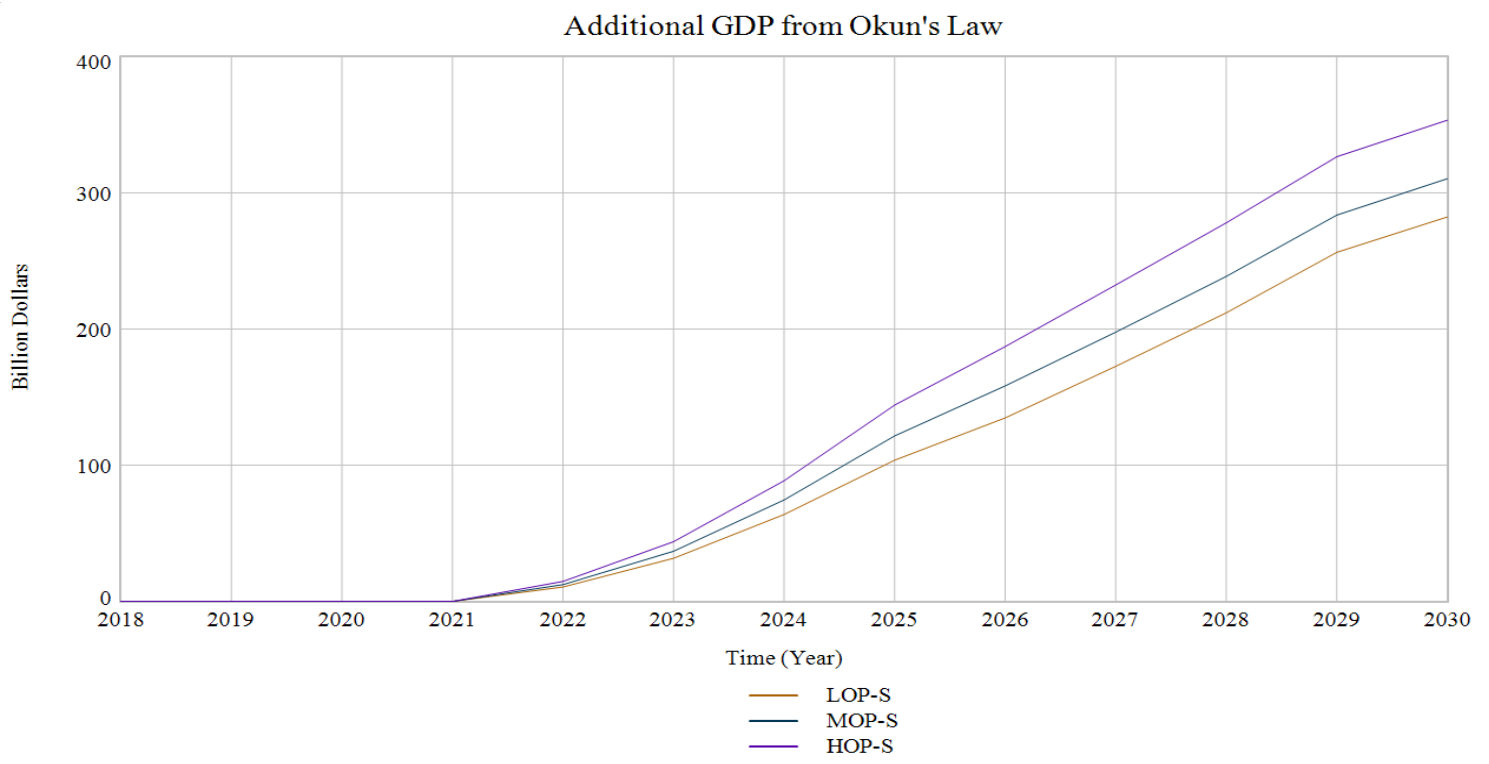

Figure 16.

LOP-S creates $\$ 282.4$ billion by 2030 for a total of $\$ 986$ billion throughout the simulation years. MOP-S creates an additional $\$ 310.5$ billion by the year 2030 and $\$ 1,124.2$ billion total. HOP-S creates $\$ 353.5$ billion as of 2030 and a total of $\$ 1,316.1$ billion.

As for the total GDP, all suggested scenarios are higher than all BAU scenarios, as shown in Figure 17.

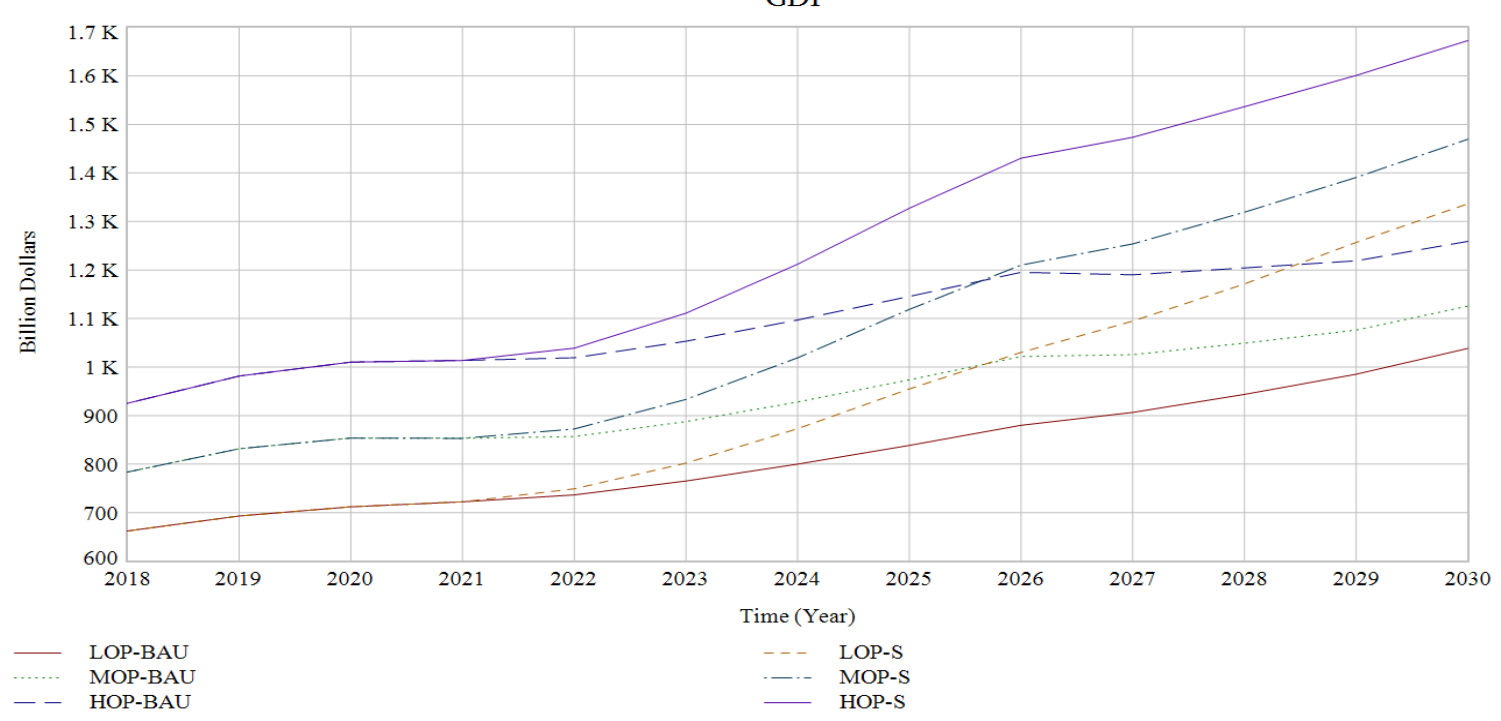

Figure 17. 
LOP-S, MOP-S, and HOP-S GDPs are $\$ 1,336.6, \$ 1,469.5$, and $\$ 1,672.9$ billion, respectively. The numbers indicate that losses can be mitigated if the kingdom decides to invest in the solar industry. Even in a low oil price scenario, the GDP performance is higher than in the HOP-BAU scenario, which is $\$ 1,259$ billion.

\section{Carbon Dioxide Emissions}

Carbon dioxide is a worldwide issue. Countries that are highly dependent on oil and developed countries suffer most from the emissions. In Saudi Arabia, with its high dependence on oil consumption, it is only logical to offer a solution to decrease the emissions considerably.

Part of the model is designed to calculate the reduction of emissions from oil-derived residential electricity. Multiplying the annual residential electricity consumption from oil by the carbon dioxide emissions equivalent will give us the annual and total residential carbon dioxide emissions (Figure 18).

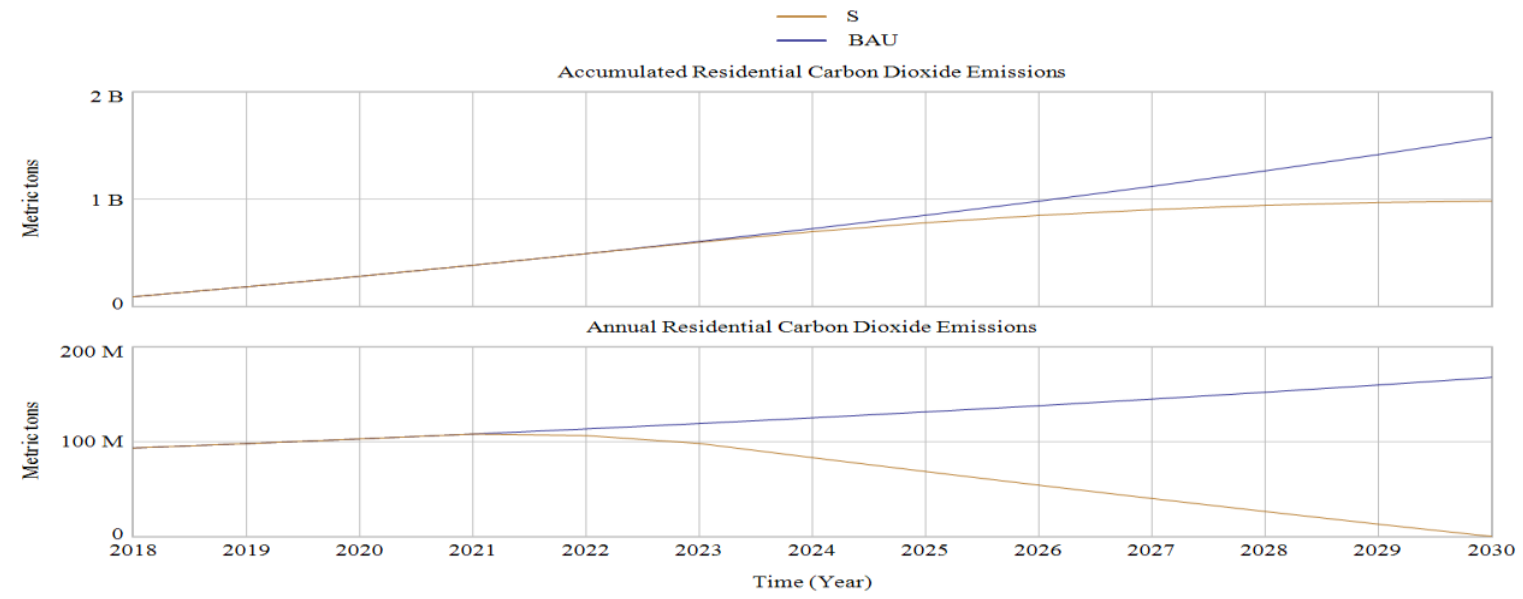

Figure 18: The Total and Annual Residential Carbon Dioxide Emissions.

By 2030, the accumulated residential carbon dioxide emissions is 983 million metric tons, compared to 1.579 billion metric tons in the BAU scenarios.

Furthermore, multiplying the equivalent by the accumulated energy saved from residential electricity will give the total reduction of carbon dioxide emissions (Figure 19).

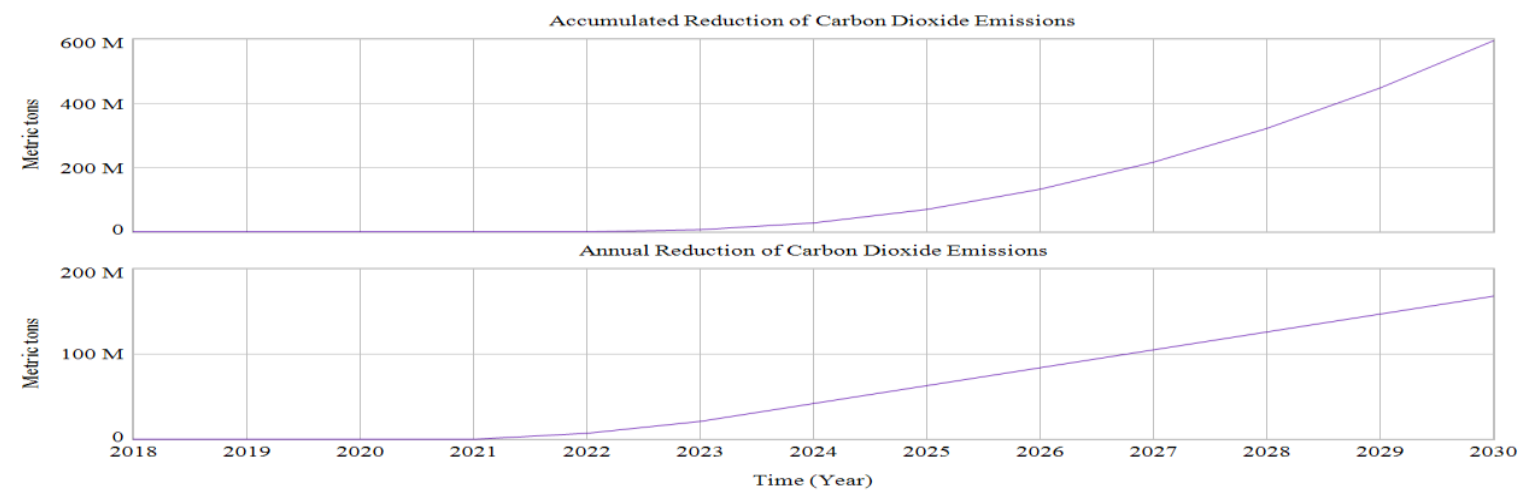

Figure 19: The Total and Annual Reduction of Carbon Dioxide Emissions.

By 2030, the scenarios save an accumulated 596 million metric tons of emissions. 


\section{Conclusion}

This study is the first SD research to reflect upon the energy-related initiatives of Vision 2030. Viewing the bigger picture and the long-term effects of investing in the solar industry helps decision-makers and investors in strategizing and deciding the best approach to pursue the economic advancement of the country.

An investment of $\$ 2$ billion is small if we compare it to the huge returns on GDP, employment, and carbon dioxide emissions. With a GDP increase from $\$ 298$ billion to $\$ 413$ billion by 2030 , the kingdom performs economically better in the LOP-S than in the high oil price scenario of the BAU.

The Saudi Vision plans to decrease unemployment by $7 \%$ by the year 2030; subjectively, this is unachievable with the current policies. Further policy improvements are needed. In our model, unemployment will cease to exist by 2030 only if the new industry's jobs prioritize Saudi employment. Saudi Arabia currently employs 213,000 foreign engineers (Al-Rugi, 2016), equivalent to 1\% of the Saudi population. There are only 16,000 Saudi engineers, making up a mere $8 \%$ of total engineers. Additionally, 687,000 women are unemployed, three times larger than the number of unemployed men (Al Jazeera, 2017). Drastic measures and parallel policies for Saudi unemployment and energy reform are needed to achieve the Saudi Vision and any developing project.

\section{Future Research}

Similar research can be done; other Saudi electric-consuming sectors can be simulated using SD. In Saudi Arabia, the industrial sector had the highest electricity consumption increase rate, and soon it will surpass the residential consumption.

\section{References}

Al Jazeera. (2017, Jul 31). Saudi Arabia unemployment rate climbs to 12.7 percent. Retrieved from http://www.aljazeera.com/news/2017/07/saudi-arabia-unemployment-rate-climbs-127-percent170730163025234.html

Al Marsd. (2017, Jan 10). Kateb Yojib An As'ela Mohayera Bekhosos “Hesab Almuwaten".. Wa Yakshif Khata' Kabeer Taqa Feh Almamlaka! [Journalist Answers Puzzling Questions Regarding “Citizen's Account".. And Reveals a Major Error The Kingdom is Making!], Retrieved from https://almarsd.com/97258.html

Al-Ahmed, K. A. (2012). Aggregate Model and Analysis of the Energy Dynamics in the Kingdom of Saudi Arabia.

Al-mulali, U. (2014). GDP growth - energy consumption relationship : revisited. https://doi.org/10.1108/IJESM-04-2013-0004

Al-Rifai, N. (2017, Mar 26). Saudi to roll out white land tax this week. Retrieved from http://www.zawya.com/mena/en/story/Saudi_to_roll_out_white_land_tax_this_week_NewspaperZAWYA20170326122056/

Al-Rugi, A. (2016, Mar 29). 230 Alf Mohandes Fi Alsaudiah.. 92\% Ajaneb [230 Thousand Engineers in Saudi.. 92\% Foreigners], http://www.aleqt.com/2016/03/29/article_1042551.html

Alyousef, Y., \& Abu-ebid, M. (2012). Energy Efficiency Initiatives for Saudi Arabia on Supply and Demand Sides.

Arab News. (2016, Jun 17). 50\% of land in big cities is vacant. Retrieved from http://www.arabnews.com/node/940746/saudi-arabia

Bloomberg. (2017, Jun 7). Saudi Arabia said to delay plans to raise energy prices. Arabian Business. Retrieved from http://www.arabianbusiness.com/saudi-arabia-said-delay-plans-raise-energy-prices680079.html 
Chien, T., \& Hu, J. (2015). Renewable energy : An efficient mechanism to improve GDP, 36(2008), 30453052. https://doi.org/10.1016/j.enpol.2008.04.012

Greenpeace. (2013). Green is Gold: How Renewable Energy can save us money and generate jobs. Greenpeace.

Kaboub, F., Forstater, M., \& Kelsay, M. (2015). The Cost of Unemployment and the Job Guarantee Alternative in Saudi Arabia.

KAPSARC. (2016). KAPSARC PV Calculator v3. Retrieved from http://apps.kapsarc.org/pvcalc/

Khan, M. M. A., Asif, M., \& Stach, E. (2017). Rooftop PV Potential in the Residential Sector of the Kingdom of Saudi Arabia, 1-20. https://doi.org/10.3390/buildings7020046

Lahn, G., \& Stevens, P. (2011). Burning Oil to Keep Cool Burning Oil to Keep Cool, (December).

Menegaki, A. N. (2014). On energy consumption and GDP studies; A meta-analysis of the last two decades. Renewable and Sustainable Energy Reviews, 29, 31-36. https://doi.org/10.1016/j.rser.2013.08.081

Ouyang, X., \& Lin, B. (2014). Impacts of increasing renewable energy subsidies and phasing out fossil fuel subsidies in China. Renewable and Sustainable Energy Reviews, 37, 933-942. https://doi.org/10.1016/j.rser.2014.05.013

Rozman, Č., Kljajić, M., \& Pažek, K. (2017). Sugar Beet Production: A System Dynamics Model and Economic Analysis, 48(3), 145-154. https://doi.org/10.1515/orga-2015-0017

Solaymani, S., \& Kari, F. (2014). Impacts of energy subsidy reform on the Malaysian economy and transportation sector. Energy Policy, 70, 115-125. https://doi.org/10.1016/j.enpol.2014.03.035

Torres, J. P., Kunc, M., \& Brien, F. O. (2017). PT US CR. European Journal of Operational Research. https://doi.org/10.1016/j.ejor.2017.01.018

Xiao, J., Cheng, J., Shen, J., \& Wang, X. (2017). A System Dynamics Analysis of Investment, Technology and Policy that Affect Natural Gas Exploration and Exploitation in China. https://doi.org/10.3390/en10020154. 